\title{
陣痛発来前に子宮破裂を来たした腹腔鏡手術後妊娠の己症例
}

\author{
大津赤十字病院 産婦人科 ${ }^{1)}$ 、京都大学大学院医学研究科 婦人科学産科学教室 ${ }^{21}$
}

佐藤幸保 ${ }^{1}$ 、丸山俊輔 ${ }^{1)}$ 、堀江昭史 ${ }^{2)}$

\section{Two cases of spontaneous uterine rupture during pregnancy after laparoscopic surgery}

\author{
Yukiyasu Sato $^{1)}$, Shunsuke Maruyama ${ }^{1)}$, and Akihito Horie ${ }^{2)}$ \\ Department of Obstetrics and Gynecology, Otsu Red Cross Hospital ${ }^{1)}$, \\ Department of Gynecology and Obstetrics, Kyoto University Graduate School of Medicine ${ }^{2)}$
}

\begin{abstract}
:
Case 1: A 29-year-old nulliparous woman underwent laparoscopic surgery to explore possible cause of infertility. Mild endometriosis was found and endometriotic lesions located on bilateral sacrouterine ligament and posterior uterine surface were extensively electrocauterized. Afterwards, the patient conceived with ICSI-ET at the age of 31 years. At $36^{+2}$ weeks' gestation, the patient complained of sudden lower abdominal pain. Fetal cardiotocogram showed persistent fetal bradycardia and she was transported to our hospital. Emergency laparotomy was performed immediately upon arrival. Prolapse of fetal lower extremity from the uterine cavity along with massive hemoperitoneum was observed and a stillborn female baby weighing $2690 \mathrm{~g}$ was extracted. Removal of accumulated blood revealed a complete longitudinal uterine rupture along the posterior uterine wall.

Case 2: A 35-year-old nulliparous woman with the history of one laparotomy and two laparoscopic surgeries underwent laparoscopic adenomyomectomy. Three months later, the patient was conceived with IVF-ET. At $28^{+5}$ weeks' gestation, the patient complained of sudden lower abdominal pain. Fetal cardiotocogram showed severe late fetal deceleration and she was transported to our hospital. On admission, massive hemoperitoneum was suspected upon examination with ultrasonography, leading to emergency laparotomy. A female baby weighing $1484 \mathrm{~g}$ was delivered by lower-segment cesarean section. Removal of accumulated blood revealed a complete longitudinal uterine rupture in the lower part of posterior uterine wall. The newborn suffered from severe intraventricular hemorrhage, resulting in diffuse cerebral atrophy.

In laparoscopic surgery, "limited use of electrocautery against the uterus" and "multilayered closure of the myometrium" should be kept in mind.
\end{abstract}

Key words: adenomyosis, endometriosis, electrocautery, myomectomy, suture

\section{【はじめに】}

妊娠中の子宮破裂は稀ではあるが、母児双方の 生命を危機にさらしうる重篤なる産科合併症であ る。その主な危険因子として、帝王切開や筋腫核 出など子宮筋層に㓔痕を残す手術の既往があげら れている。

腹腔鏡手術の技術進歩にともない、その適用範 囲は広がり、子宮筋腫、腺筋症、内膜症など婦人
科良性疾患に対する手術のほとんどが腹腔鏡下に 行われるまでになった。腹腔鏡手術は開腹手術に 比べて、手術創の縮小、疼痛の軽減、入院期間の 短縮などメリットは多い1)。しかし、腹腔鏡下の 筋腫核出術や腺筋症摘出術では開腹下に比べて、 筋層欠損部の修復が不完全となりやすく、その後 の妊娠中の子宮破裂のリスクが高くなることが危 惧されている2)。

腹腔鏡下筋腫核出術後の妊娠中に子宮破裂をき 
たした19症例の後方視的検討によると、19例中 9 例は正常筋層への影響が比較的少ない漿膜下筋腫 の核出であり、9例すべてで電気デバイスによる 焼灼止血が行われていた。9例中縫合が行われて いたのは 2 例に過ぎず、残りの 7 例では止血のた めに過剩な焼灼を行なった可能性が示唆された。 また、 2 層以上の多層縫合が実施されていたのは 19例中 3 例に過ぎなかった。以上より、著者らは 「子宮への焼灼を最小限にすること」と「子宮筋 の欠損部を多層縫合で修復すること」の 2 点が重 要であると結論づけている ${ }^{2)}$ 。

今回、我々は腹腔鏡手術後の妊娠中に陣痛発来 前の子宮破裂をきたし、胎児に重篤な転帰をもた らした 2 症例を経験したので報告する。

\section{[症例]}

1 ) 症例 1

主訴 : 突然の下腹痛

妊娠分婏歴：0 経妊 0 経産

既往歴：0歳 先天性右腎欠損

現病歴：

29歳時に不妊原因の探索のため腹腔鏡手術を施 行された。軽症の子宮内膜症を認め、両側仙骨子 宮勒带および子宮後面の内膜症病変を電気デバイ スにて広範囲に焼灼された（図 $1 \mathrm{~A} ）$ 。その後、夫 のそ精子症が明らかとなり、31歳時に顕微授精を 施行され妊娠に至った。

妊娠初期より前医で妊婦健診を受けていたが、 特に問題なく経過していた。妊娠35週 6 日に切迫 早産の診断で入院となり、塩酸リトドリンを点滴 されていた。妊娠36週 2 日 $22: 30$ 突然の下腹痛 および $60 \mathrm{bpm}$ の胎児持続性徐脈が出現、当科に救 急搬送となった。搬送中に胎児心音はドプラーで

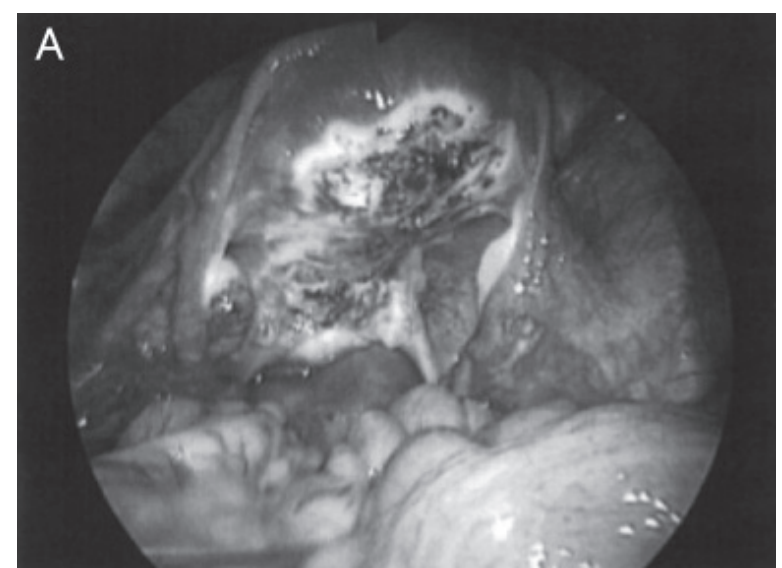

聴取できなくなった。23：13当科に搬入、23:23 手術室入室、 $23: 31$ 全身麻酔下に緊急開腹術を開 始した。腹腔内には大量の血液が充満しており、 その中に胎児の下肢が確認できた。児はすでに死 亡しており、子宮を脱出して上腹部に位置してい た。下肢を牽引して、2690g女児を娩出した。腹 腔内に貯留した大量の血液を除去すると、男子手 拳大に退縮した子宮が確認できた。子宮後壁は縦 方向に約 $40 \mathrm{~cm}$ にたって完全に断裂しており、 破裂創下端から動脈性の出血を認めた（図1B）。 破裂創は 3 層縫合で修復した。

手術直後のへモグロビンは $5.9 \mathrm{~g} / \mathrm{dl}$ まで低下し たが、患者の強い要望で輸血をせずに鉄剂投与の みを行った。術後14日目にへモグロビンは $9.2 \mathrm{~g} /$ dlまで回復し、15日目に退院した。

\section{2) 症例 2}

主訴：頻回な子宮収縮をともなう下腹痛 妊娠分婏歴：0 経妊 0 経産

既往歴：

$\mathrm{X}-12$ 年 8 月 $(23$ 歳)

開腹両側内膜症囊胞核出術

○左 $6 \mathrm{~cm}$ 、右 $1 \mathrm{~cm}$ のチョコレート襄胞を核出。 $\mathrm{X}-6$ 年 2 月 ( 29 歳)

腹腔鏡下右内膜症性囊胞核出術

○再発した右チョコレート襄胞を核出。

$\mathrm{X}-3$ 年 6 月 (32歳)

腹腔鏡補助下筋腫核出および癒着剥離術

○再発した左チョコレート襄胞を核出。

○完全閉鎖したダグラス窩を開放。

$1 \mathrm{~cm} 、 3 \mathrm{~cm} 、 4 \mathrm{~cm}$ 大の筋腫を核出、直視 下に縫合閉鎖。

$\mathrm{X}$ 年 1 月 (35歳)

図1. 症例 1 における腹腔鏡手術中写真（A）と妊娠中の子宮破裂部位（B) A. 子宮後面が広範囲にわたって電気焼灼されている。

B. 子宮後壁が縦方向約 $40 \mathrm{~cm}$ にわたって完全に断裂し、破裂創下端より動脈性出血を認める。破裂創は子宮後面の焼灼部位と一致している。 
腹腔鏡下腺筋症摘出および癒着剥離術(図2A, B)

○完全閉鎖したダグラス窩を開放

ダグラス窩の深部内膜症病変を摘出。

子宮後壁を正中縦切開して腺筋症を切除、腹 腔鏡下に縫合閉鎖。

現病歴 :

最終手術の 3 ケ月後のX年 4 月に凍結融解胚盤 胞 1 個を移植し妊娠に至り、前医で妊婦健診を受 けていた。妊娠初期に少量の性器出血を反復した が、それ以外は経過順調であった。妊娠28週5日 夜間に突然の下腹痛が出現し、前医を救急受診し た。頻回な子宮収縮とそれにともなう胎児心拍数 の低下を認めたため、当科へ救急搬送された。

入院時所見：

母体バイタルサイン

血圧 $70 / 46 \mathrm{mmHg}$ 、脈拍数 $104 /$ 分 (ショック・

インデックス1.49)

母体血液検査

ヘモグロビン $7.1 \mathrm{~g} / \mathrm{dl}$ 、ヘマトクリット $20 \%$

( 2 時間前の前医での検査ではへモグロビン $11.1 \mathrm{~g} / \mathrm{dl} 、$ ヘマトクリット $31.9 \%)$

経腹超音波検査

腹腔内に新鮮な血液貯留を思わせる無エコー域 あり
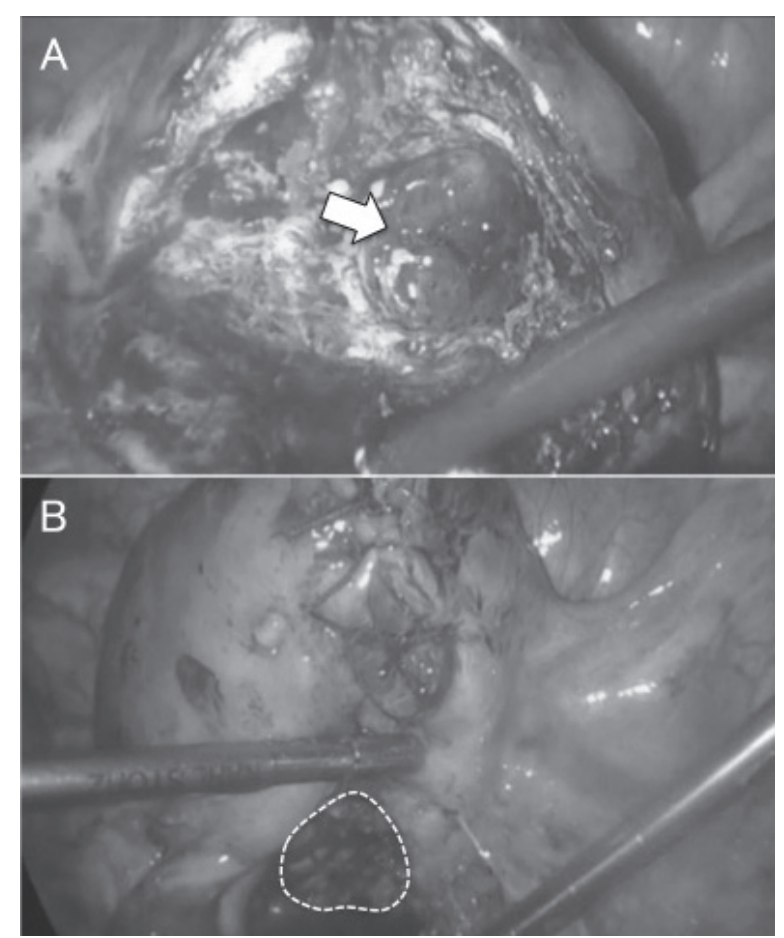

胎児心拍モニター所見

頻回な子宮収縮にともなう高度遅発一過性徐 脈、基線細変動の消失

入院後経過：

子宮破裂を疑い、日が変わった妊娠 28 週 6 日深 夜に緊急開腹術を施行した。開腹時、腹腔内には 大量の血液が貯留していた。子宮下部横切開にて 体重 $1484 \mathrm{~g}$ 女児を $\mathrm{Ap}^{-1} 1$ 点/ $\mathrm{Ap}^{-5}$ 6点にて婏出し た。腹腔内に貯留した大量の血液（約 $3,000 \mathrm{ml}$ ) を除去したところ、子宮後壁下部が縦方向に約 $20 \mathrm{~cm}$ にたって完全に断裂していることが判明 した（図2C）。破裂創は 3 層縫合で修復した。術 中に濃厚赤血球 8 単位、新鮮凍結血漿 4 単位を輸 血した。

母体は手術直後にへモグロビン $7.7 \mathrm{~g} / \mathrm{dl}$ の高度 貧血を認めたが、鉄剤投与のみで術後 5 日目には $10.4 \mathrm{~g} / \mathrm{dl}$ まで回復し、7日目に退院した。出生児 は重度の脳室内出血、その後びまん性脳萎縮をき たした。

\section{【考察】}

通常の開腹下筋腫核出術後の妊娠における子宮 破裂の頻度は0.5 0.7\% と推定され、古典的帝王 切開 (子宮体部縦切開) 術後の妊娠における子宮 破裂の頻度 $\left(1\right.$ ～12\%)よりも低いとされている ${ }^{3)}$ 。 腹腔鏡下筋腫核出術を施行された2,050症例を対 象にした多施設共同研究によると、挙児希望のあ つた553例のうち386例で術後に妊娠が成立した。 そのうち309例が分婏まで至っているが、子宮破 裂をおこしたのは 1 例 $(0.3 \%)$ に過ぎなかった。 これは開腹下筋腫核出術後の妊娠における子宮破 裂の頻度と同等であり、著者らは経験のある術者 が行なう限り、腹腔鏡下筋腫核出術は安全な手術

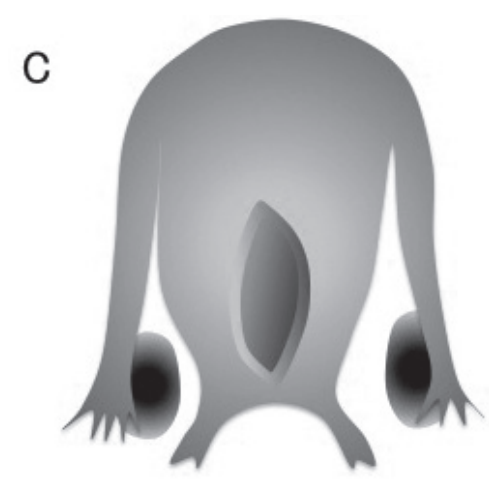

図2. 症例 2 における腹腔鏡手術中写真（A, B ）と妊娠中の子宮破裂部位（c）

A． 腺筋症核出直後。広範囲にわたって子宮後壁の筋層が欠損しており、一部で子宮内膜が膨隆している(矢印)。

B. 筋層欠損部の縫合閉鎖後。下部（破線で囲まれた部位）が縫合されていない。

C. 子宮後壁下部が縦方向約 $20 \mathrm{~cm}$ にわたって完全に断裂している。破裂創は腹腔鏡手術で筋層欠損部の縫合がなされていなかった部位と一 致している。 
であると結論づけている゙)。

今回の陣痛発来前の子宮破裂は、いずれも腹腔 鏡手術後の初回妊娠で発症し、児に死亡およびび まん性脳萎縮という重篤な転帰をもたらした。症 例 1 では、腹腔鏡下内膜症手術後 2 年で妊娠が成 立し、妊娠36週で子宮破裂をきたした。破裂部位 は子宮後面の電気焼灼部位と一致しており、内膜 症病変に対する過剩な焼灼による子宮筋の脆弱化 が主因と考えられた。症例 2 では、4回目の手術 である腹腔鏡下腺筋症摘出術後 3 ヶ月で妊娠成立 し、妊娠 28 週で子宮破裂をきたした。破裂部位は 摘出後の子宮筋層欠損部位のうち縫合がなされて いなかった子宮後面下部と一致しており、不完全 な縫合修復が主因と考えられた。

子宮腺筋症は筋腫と異なり周囲の筋層へ浸潤す るように増殖するため、正常子宮筋層との境界は 不明膫なことが多い。したがって、腺筋症摘出術 では摘出部位の正常平滑筋細胞数が減少すること が避けられず、必然的にその後の妊娠中の子宮破 裂の危険性は筋腫核出術後よりも高くなる。実際、 Wadaらは自験例と過去の報告例を合わせた子宮 腺筋症摘出術後の妊娠19例のうち 2 例 (11\%) が 妊娠中に破裂をきたしていたと述べている5)。腺 筋症摘出術後妊娠でおこりうる子宮破裂を回避す るためには、摘出に引き続く子宮筋欠損部位の適 切な再建が不可欠と考えられ、種々の方法が考案 されている ${ }^{6)}$ 。これらの再建術には複雑な縫合を 要するものも多く、腹腔鏡下での実施には熟練し た技量が必要となる。著者らはOsadaらが提唱す る triple-flap method ${ }^{7)}$ を取り入れ開腹下に行って いるが、現在までに経験した 2 例の術後妊娠症例 はいずれも妊娠満期まで問題なく経過し、予定帝 王切開で分婏に至った。以上より、子宮腺筋症摘 出術については、腹腔鏡手術にこだわらず、開腹 あるいは腹腔鏡補助下に子宮筋欠損部位の十分な 再建を行うべきであると考えている。

子宮筋腫や腺筋症など子宮腫瘍の核出をともな わない腹腔鏡下子宮内膜症手術後の妊娠中に子宮 破裂をきたすことは非常にまれであり、著者らの 文献検索では 2 例の症例報告があるのみであっ た ${ }^{8.9)}$ 。この 2 例はいずれも腹腔鏡下に直腸腟中隔 にある梁部内膜症病巣を切除したものであり、止 血目的の子宮への電気焼灼以外に危険因子と考元 うるものはなかった。子宮表面への電気デバイス による焼灼は術者が考える以上に子宮筋の脆弱化 をもたらす可能性のあることを十分に認識すべき であろう。近年、消化器科や耳鼻咽喉科領域で用
いられるようになったアルゴンプラズマ凝固は、 極めて深達度が浅く深部組織への影響を最小限に できるため、子宮のみならず骨盤腹膜表面の子宮 内膜症病巣の焼灼にも有用と考元られ。

今回の 2 症例は、いずれも他院で腹腔鏡手術を 行なわれ、体外受精および妊娠後の健診も別の病 院でなされており、子宮破裂を来してから当院に 搬送されたものであった。体外受精を施行した病 院に問い合わせたが、いずれも妊娠許可前に子宮 筋層の評価はされていなかった。今後は、腹腔鏡・ 開腹にかかわらず、筋腫核出や腺筋症摘出など子 宮筋層におよぶ手術を受けた症例については妊娠 許可前に骨盤MRIを撮影し、その後子宮破裂を起 こした症例について後方視的に検討することで、 妊娠許可基準を確立していくことが重要と思われ る。

\section{【結 語】}

腹腔鏡手術後の妊娠中に陣痛発来前の子宮破裂 をきたし、児に重篤な転帰をもたらした 2 症例を 経験した。症例 1 では子宮表面の内膜症病変に対 する過剩な焼灼、症例 2 では腺筋症核出創部の不 完全な縫合修復が破裂の主因と考えられた。腹腔 鏡手術にあたっては、「子宮への電気焼灼を最小 限にすること」および「子宮筋欠損部を完全に修 復すること」に留意すべきである。

\section{【文献】}

1 ) Jin C, et al. Laparoscopic versus open myomectomy-a meta-analysis of randomized controlled trials. Eur J Obstet Gynecol Reprod Biol. 2009 ; 145 (1) : 14-21.

2) Parker WH, et al. Risk factors for uterine rupture after laparoscopic myomectomy. J Minim Invasive Gynecol. 2010 ; 17 (5) : 551-4.

3) Landon MB, Lynch CD. Optimal timing and mode of delivery after cesarean with previous classical incision or myomectomy : a review of the data. Semin Perinatol. 2011 ; 35 (5) : 257-61.

4) Sizzi O, et al. Italian multicenter study on complications of laparoscopic myomectomy. J Minim Invasive Gynecol. 2007 ; 14 (4) : 453-62.

5) Wada S, Kudo M, Minakami H. Spontaneous uterine rupture of a twin pregnancy after a laparoscopic adenomyomectomy : a case report. J Minim Invasive Gynecol. $2006 ; 13$ (2) : 166-8.

6) Grimbizis GF, Mikos T, Tarlatzis B. Uterus-sparing operative treatment for adenomyosis. Fertil Steril. $2014 ; 101$ (2) : 472-87.

7) Osada H, et al. Surgical procedure to conserve the 
uterus for future pregnancy in patients suffering from massive adenomyosis. Reprod Biomed Online. $2011 ; 22$ (1) : 94-9.

8) Van De Putte I, et al. Uterine rupture following laparoscopic resection of rectovaginal endometriosis : a new risk factor? Br J Obstet Gynaecol. $1999 ; 106$ (6) : 608-9.

9) Villa G, et al. Uterine rupture in a primigravida with adenomyosis recently subjected to laparoscopic resection of rectovaginal endometriosis : case report. J Minim Invasive Gynecol. 2008 ; 15 (3) : 360-1. 